\title{
高齢者・障害者のためのユビキタスネットワークロボット技術 の研究開発
}

Ubiquitous Networked Robots for the Elderly and the Physically and Mentally Challenged Disabled People

萩 田 紀 博* *ATR 知能ロボティクス研究所

Norihiro Hagita* *ATR Intelligent Robotics and Communication Laboratories

\section{1. は じめ に}

高齢者や障害者等が安心して暮らせる社会の実現を目指 して，高齢者らの見守りや介護者の肉体的・精神的負担軽 減のために様々なサービスロボットの研究開発が進められ ている。これらの安全基準や標準化が確立されていくこと と並行して，ロボット同士の協調・連携や携带端末，環境 センサの情報を共有できるネットワークプラットフォーム 構築もロボット関連ビジネスを生み出すために不可欠な研 究開発である。すなわち、ロボット単体のサービスに留ま らず，高度化が進む情報通信技術（ICT）を最大限利用し た新しいロボット関連市場が生まれてくる。この考え方は, 携帯電話やスマートフォンの利用状況を見れば明らかであ る．携带電話 1 台（単体）がどんなに高機能になってもク ラウドコンピューティングやインターネットなどのインフ ラがなければ市場は生まれない。ロボットはヒューマンイ ンタフェース, アクチュエーションなどの視点からみて, 携 帯端末とは相補的な関係が多くある。例えば，ロボットは 移乗，把持などの力を補助することができ，人型ロボット やアンドロイドでは端末の操作が不要になるため高齢者や 障害者（チャレンジド）などが親しみやすい対話とジェス チャで情報をやり取りすることが可能になる.

我が国では 2003 年からロボット同士や携带電話，環境セ ンサ群とインターネットを介して協調・連携するネットワー クロボットの研究開発を進めている [1]. 韓国でも同様のコ ンセプトで 2004 年来, ユビキタス型ロボット連携の実証実 験が行われた $[2]$. 欧州でも 2006 年以降，スペインを中心 とする URUS [3]，イタリアを中心とするDustBot [4] など ネットワークロボット研究プロジェクトが進められている. ユニバーサルシテイウォーク大阪で我が国が開発したネット ワークロボットプラットフォーム $[5]$ やセンサーネットワー ク [5] をベースにして, Honda 社製 ASIMO, DustBotと ATR のロボットとの連携実験が可能であることを実証し

原稿受付 2010 年 8 月 9 日

キーワード : Network Robots, Multi-robot Collaboration and Coordination, Life Support Robotics, Tele-operation

* ₹ 619-0288 相楽郡精華町光台 2-2-2

* Soraku-gun, Kyoto
た [6] [7]. 米国でも 2003 年のロボカップをヒントに Kiva Systems が開発したネットワークロボット技術が 2005 年 に Staples 社配送センター [7] に導入され，現在全米 12 社 に広がっている。2009年からもべンチャー企業を中心に遠 隔操作を前提としたネットワークロボットの商用化 [8] が進 められている。

本解説では, 高齢者や障害者等が生活利便性を向上し, 社会参加しやすくするために, 多地点でロボットサービス を連携できるネットワークロボットの研究開発を紹介する. 多地点連携のロボット・システムをユビキタスネットワー クロボットと呼び, 2009 年度から, 総務省委託研究「高齢 者・障害者のためのユビキタスネットワークロボット技術の 研究開発」(実施機関：ATR，東芝，NTT，日立製作所，日 本電気）を開始した。ここでは，ATR が行っているロボッ 卜連携買物支援と高齢者対話支援実験について紹介する。

\section{2. 単地点から多地点ネットワークロボットへ}

ネットワークロボットの概念に基づいて，これまでに商 店街，駅，科学館などの人が行き交う場所（単地点）にお いて，ロボットが連携して道案内，来店誘導，展示物説明 などの対話サービスを実現できることを示した [1]. ユビキ タスネットワークロボット技術の研究開発では, 多地点で サービスを連携できるプラットフォーム技術を開発してい る，そのなかで，高齢者の社会参加を支援する視点から，一 人ひとりの高齢者を対象にして，多地点にわたってサービ 又連携を行うロボット連携買物支援実験と介護者の負担軽 減の視点からロボットが高齢者（チャレンジドを含む）同 士のテレビ電話による対話を支援する遠隔対話支援実験に ついて紹介する。

\section{3. ロボット連携買物支援実験}

\section{1 ねらい}

高齢者（特に独居の方）にとって買い物は重要な生活行 動の一つである．しかしながら，值札が見えづらい，欲し い商品がどこにあるか分からないなどが重なると，買い物 に行くことが億劫になり，引きこもりがちになってしまう という．地域のボランティアやインターネットによる買物 


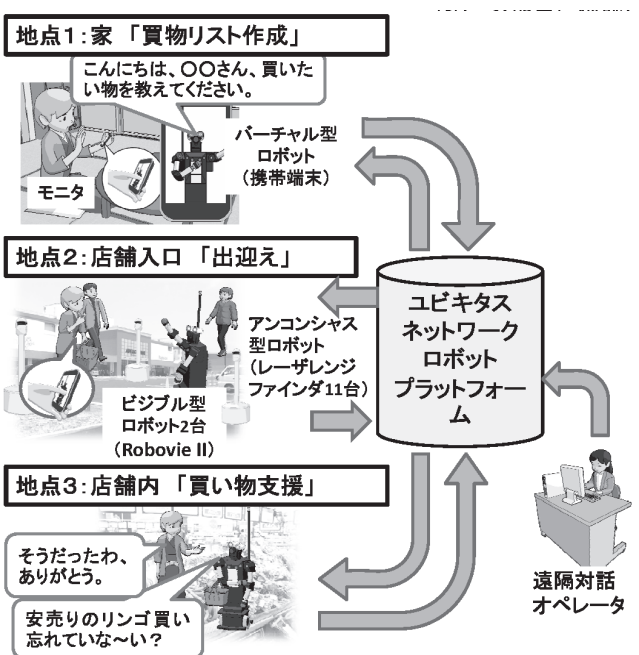

図 1 多地点に拡張したネットワークロボットシステム（ユビ キタスネットワークロボット)

代行サービスなども実施されているが，日常的に不可欠な 買い物を何度も他人にお願いしなければならないという精 神的な負担も指摘されている. 家族のようにもっと気軽に 話せる相手と楽しく対話しながら買い物ができたらという 高齢者の意見も強い.

\section{2 実験概要}

図 1 に示すように, 家, 店舗入口, 店舗内の 3 地点で, そ れぞれ，「買い物リス卜作成」「出迎え」，「買い物支援」の 各サービスを連携させる実験を京都府のアピ夕精華台店で 2009 年 12 月から行った。現実のネットワーク環境はいつ でもどこでもリッチなセンサ環境を実現できるわけではな い，そこで，環境センサがない場所においても，このサー ビスを実行できるように，オペレー夕による遠隔対話と 3 地点で異なるセンサ粒度を設定した。

まず，「家」（地点 1）で，スマートフォンを使って, 高 齢者（モニタ）は遠隔オペレータと一緒に買物リストを作 る. 次に, モニタが店舗に来店すると,「店舗入口」（地点 2) で, 環境センサ（レーザーレンジファインダ 11 台と無線 LAN アクセスポイントからなる) が, 来店者の位置 (人の 腰高上の二次元平面位置座標）を $5[\mathrm{~cm}]$ の精度で正確に計 測する. システムが携帯端末の個人 ID（携帯端末の MAC アドレス）を検出することによってモニタが誰であるかを 特定できる，このあとに，ビジブル型ロボット（Robovie II）がターゲットとなるモニタに近づいて，「○○さん，お 待ちしていました」などと言って，抒迎えをする。

その後,「店舗内」（地点 3) では, 家で決めた買物リス トに従って, ビジブル型ロボット [1] が順に商品棚まで付き 添い，モニ夕の買い物を支援する。センサ環境は設置せず Robovie II 自体のカメラとマイクロフォンだけの情報でオ ペレータが対話する。例えば，モニタが買い忘れそうになっ

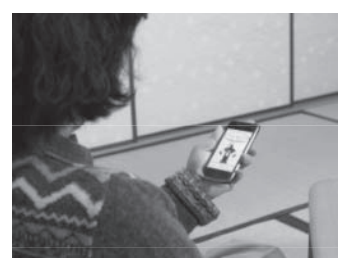

(a) 家 買物リスト作成

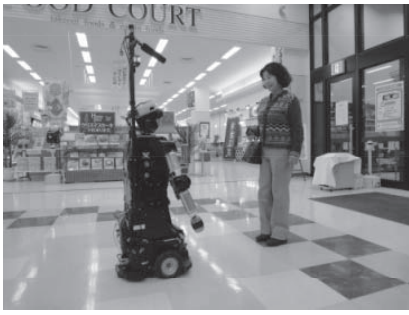

(b)店舗入口 出迎え

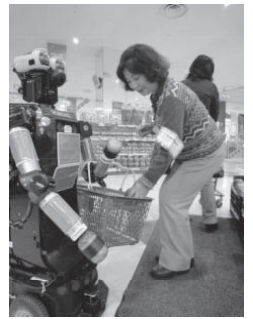

(c)店舗内買物支援
図 2 買い物支援ロボットサービス実験の様子

た商品があれば，ロボットが「あ，○○を買うのを忘れて るよ」というょうに, 一緒に買い物している感覚で買い物 のアドバイスを行う。本実験では, 遠隔オペレー夕（研究 者）が各地点のモニ夕と遠隔対話・操作を行った（図 2 ）. モニタとロボットとの楽しい対話を観測でき，インタラク ション行動シナリオの開発に利用していく予定である.

\section{4. 事例 2：遠隔対話支援実験}

\section{1 ねらい}

2006 年に, 高齢者（左側）と傾聴ボランティア（右側） をテレビ電話で結ぶ遠隔傾聴実験を実施し, 家族（介助者） の負担軽減と高齢者のコミュニケーションの注意持続に有 効であった $[9]$ が, 資格を持った傾聴ボランティアの数そ のものが析違いに少ないという問題が残されている. そこ で, この喫緊の課題を解消するために, 本実験では介助者 の代わりにビジブル型ロボットとカメラを導入して, かつ 高齢者同士が対話する遠隔対話支援ロボットサービス実験 を行った。

\section{2 実験概要}

他者とのかかわりが少なくなりがちな高齢者にネットワー クを介した対話機会を提供することで，コミュニケーショ ン意欲を高め孤立感の解消など情緒面でのサポートを行え るかを実験した，予備検討として，認知症者 10 名を含む高 齢者 12 名から二人同士によるテレビ会議システムを利用 した遠隔対話の観察を実施し，ユーザの注意低下により対 話の持続が困難になること，ユーザに付き添う対話介助者 によってユーザの注意を対話相手に引き付けることができ ること, 一方で対話介助者の過度の介入により高齢者同士 の対話が阻害される場合があることなどの知見を得た．

この予備検討の結果に基づいて, 実験評価システムでは, 


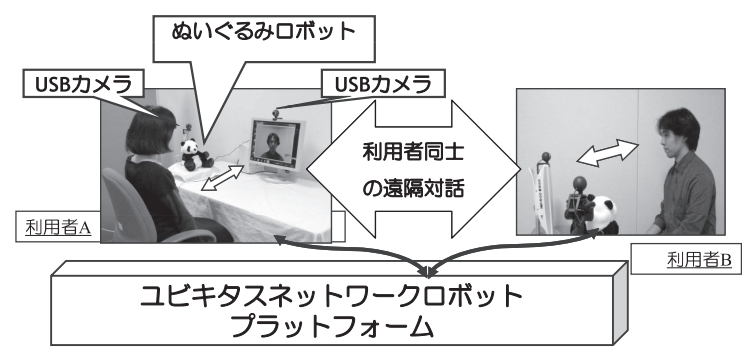

図 3 遠隔対話支援ロボットサービス実験

対話介助者の役割をビジブル型ロボットにより代替するた め, マイクとカメラによるユーザの対話態度（顔向き・発 話の有無）の検出, 領き・手振り等のジェスチャ表出, ルー ルベースの発話による相桘・話題提供等の機能を実装した （図 3). 同システムを用いた機能評価のために精華町社会 福祉協議会デイサービスセンターに抏いて 2009 年 12 月に 実施した実証実験では，同センターに通所する高齢者 12 名 の参加を得てシステムの基本機能の動作を検証するととも に，ビジブル型ロボットによる対話支援機能により初めて 参加する高齢者同士でもテレビ会議システムによる遠隔対 話が成立することを確認できた。

\section{5.おわりに}

本報告では，一人のユーザに多地点で異なるロボットサー ビスを連携可能にするためのユビキタスネットワークロボッ 卜実験として，ロボット連携買物支援実験掞よび高齢者同 士の遠隔対話支援ロボットサービス実験を紹介した。これ以 外にもアジア太平洋トレードセンター（ATC）でもロボッ トサービス実験を進めている。これらの実験を通じて, 多 地点でのネットワークロボットが高齢者や障害者（チャレ ンジド）の社会参加を支援する新たな道具になっていく可 能性を切り開くとともに関連する標準化活動も並行して実 施する予定である。

謝 辞 本報告は総務省の研究委託により，実施したも
のである．実験にご協力いただいたアピタ精華台店および 京都府の精華町社会福祉協議会デイサービスセンターに感 謝致します．日ごろ，議論しているATR 知能ロボティク 又研究所員, 特に秋本高明室長, 宮下敬宏室長, 篠沢一彦 室長, 安部伸治室長, 小泉智史研究員, 佐竹聡研究員に深 謝します。

\section{参 考 文 献}

[1] 萩田紀博: “ネットワークロボット概論”, 電子情報通信学会誌, vol.91, no.5, pp.346-352, 2008.

[2] W. Yu, J.-C. Sohn and Y.-J. Cho: "Design and Implementation of a Ubiquitous Robotic Space," Proceedings of Workshop on Network Robot Systems in 2008 IEEE/RSJ International Conference on Intelligence Robots and Systems (IROS2008), NRS-6, 2008.

[3] A. Sanfeliu and J. Andrade-Cetto: "Ubiquitous networking robotics in urban settings," Proceedings of Workshop on Network Robot Systems. Toward Intelligent Robotic Systems Integrated with Environments in 2006 IEEE/RSJ International Conference on Intelligence Robots and Systems (IROS2006), 2006.

[4] DustBot プロジェクト, http://www.dustbot.org/index.php?menu $=$ home

[ 5 ] 萩田紀博: “環境情報構造化とネットワークロボット”, ロボット, no.181, pp.11-17, 2008 .

[ 6 ] http://robonable.typepad.jp/news/2008/12/20081226-atrasi.html

[7] http://www.willowgarage.com/

[8] http://anybots.com/, http://www.intouchhealth.com/

[9] Erico Guizzo: "When my avator went to work," IEEE Spectrum, vol.47, no.9, pp.24-29, 2010.

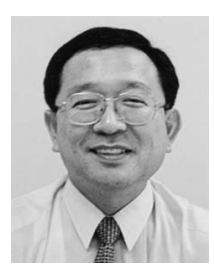

萩田紀博（Norihiro Hagita）

1978 年慶應義塾大学大学院工学研究科電気工 学専攻修士課程修了. 同年電電公社 (現 NTT) 武蔵野電気通信研究所入所. NTT 基礎研究所, ATR メディア情報科学研究所長などを経て, 現在 ATR 知能ロボティクス研究所長.この 間, 文字認識, 画像認識, コミュニケーショ ン科学、コミュニケーションロボットなどの研究に従事. 工学 博士. IEEE, 電子情報通信学会, 情報処理学会, 人工知能学会 各会員.

（日本ロボット学会正会員） 